\title{
An endogenous money perspective on the post-crisis monetary policy debate
}

\author{
Scott T. Fullwiler \\ Wartburg College, Waverly, IA and Presidio Graduate School, San Francisco, CA, USA
}

\begin{abstract}
A number of debates are taking place regarding the appropriate response of monetary policy both to the crisis and the Great Recession that followed, particularly in regard to interest on reserve balances and so-called unconventional monetary policy operations. This paper describes in detail an endogenous money perspective on the interactions between central bank operations and banks, and then shows that interest on reserve balances does not impede the transmission of monetary policy, while quantitative easing does not necessarily enhance it.
\end{abstract}

Keywords: endogenous money, central bank operations, interest on reserves, quantitative easing

JEL codes: $E 43, E 52, E 58$

\section{INTRODUCTION}

One might think that the endogenous money view (for example, Moore 1988) had been vindicated by the financial system's actions during the housing bubble's construction during the 2000s and the central banks' subsequent responses to the resulting financial crisis and recession. The well-known absence of a banking system from New Consensus macroeconomic models in the midst of a mortgage-based housing bubble and collapse or the absence of an economically significant increase in measured inflation 4 years after the start of historically large expansions in the Fed's balance sheet and the monetary base might arguably be considered to be two devastating examples of the inapplicability of neoclassical monetary economics. To some degree, there has been movement in the sense that there is renewed interest in research on central bank operations and financial markets, and integrating these into models of monetary transmission mechanisms. On the other hand, none of these advances has made its way into textbooks at any level, and endogenous money remains mostly unexplored territory even in this new round of research, save for a few notable examples.

The purpose of this paper is to both restate how endogenous money and central bank operations are integrated, and then to consider how these are related to some of the current policy debates related to monetary theory and monetary operations. It first describes in some detail bank operations within the context of monetary policy from an endogenous money perspective. In particular, it deals with the question of whether banks are deposit and/or reserve constrained and integrates this into an analysis of a bank's basic business model. Next, the necessarily accommodating nature of central bank operations given that banks create credit-driven money endogenously and the central bank must defend the payments system is described within the context 
of supply and demand in the interbank market. These insights are used to understand how interest on reserves and quantitative easing, and in particular why neither is overly significant in terms of its effects on the economy, even as both are very significant for understanding how central bank operations and monetary policy actually function.

\section{ARE BANKS DEPOSIT AND/OR RESERVE CONSTRAINED?}

\subsection{The business model of banks}

Unlike non-financial corporations, banks (and other financial institutions) have a business model driven by leverage. The easiest way to understand this is to consider the formula for return on equity and apply the DuPont Expansion that is found in every introductory finance text:

$$
\begin{gathered}
\text { Return on Equity }(\mathrm{ROE})=\text { Profits / Equity } \\
\text { ROE }=\text { Profits } / \text { Equity }=(\text { Profits } / \text { Assets }) \times(\text { Assets } / \text { Equity })
\end{gathered}
$$

The ratio (Assets / Equity) is called the equity multiplier or leverage. As it is in fact a measure that rises as a company adds more debt relative to equity, leverage is the more intuitive term. The ratio (Profits / Assets) is the return on assets; every company in every industry except the financial industry must find a way to generate a healthy return on assets. This is because non-financial corporations do not rely on leverage to earn a return on equity: excessive borrowing can reduce credit ratings and result in debt service rising to dangerous levels. As such, return on equity for them comes primarily through the return on assets, though with significant variation across companies and industries.

Banks on the other hand routinely hold about 7 or 8 percent of their assets as equity (except for the smaller banks, which hold about 10 percent), leaving banks with a leverage of around 12 to 14; by comparison, a leverage approaching 2 (that is, 50 percent liabilities on the balance sheet) is considered quite high for a non-financial corporation. To earn a 15 percent return on equity (the average for US banks from the mid-1990s to the mid-2000s), such a bank would only need to earn 1.1 to 1.25 percent return on assets given leverage between 12 and 14 (all bank ratio data is from Bech and Rice 2009). A 1.5 percent return on assets is considered to be rather good for a bank, although it is a poor number for a non-financial corporation. Banks earn such a low return on assets because their assets earn little revenue compared to a non-financial corporation that produces goods to sell with its assets. For instance, a bank earning 5 percent average interest on its assets would require a 20 percent profit margin to achieve a 1 percent return on assets. Expanding the return on assets formula illustrates this:

$$
\begin{gathered}
\text { Return on Assets }=(\text { Profits / Assets }) \\
\text { Return on Assets }=(\text { Profits } / \text { Revenues }) \times(\text { Revenues } / \text { Assets })
\end{gathered}
$$

The ratio (Revenues / Assets) is the company's turnover (or total asset turnover), and for a company earning 5 percent average interest on all assets, the turnover would 
be 0.05 . The ratio (Profits / Revenues) is the profit margin. A 20 percent profit margin and a turnover over of 0.05 yields a return on assets of 1 percent $(1=20 \times 0.05)$. While banks achieve respectable or even high profit margins, their business model will always leave them with exceptionally low turnover relative to non-financial corporations, and thus very low return on assets in comparison. Greater leverage is how banks and other financial institutions make up for this disparity.

A bank can afford such high leverage because its debt - or liabilities - earn significantly less than those for a non-financial corporation. The most significant of these is obviously traditional deposit accounts, for which banks pay next to nothing, or even less than that when fees and so forth charged to depositors are accounted for. Even with savings accounts, time deposits, and money market borrowings, a bank's total cost of liabilities should be less than average interest earned on assets. Banks can thereby carry 90 percent or more of their balance sheet as liabilities without the consequences of falling credit ratings and rising debt service that would befall a non-financial corporation. Indeed, this maximization of leverage is the financial side of the bank's business model revenues from bank assets are less than returns required by owners, let alone the returns they bring after accounting for costs. The only way to provide required returns to owners is then to leverage the earnings from the assets with 'investments' of creditors, which in this case are depositors, savings account holders, and so forth. Again, leverage is obviously common with non-financial corporations - creditors that require less return enable owners to earn higher returns than otherwise - but it is not central to the business model as it is to financial institutions.

Given a bank's desire to maximize leverage coupled with government insurance of bank deposits, the government sets a limit to bank leverage via regulation in order to limit its own risks. As the bank's business model is to lend at an interest rate higher than its liabilities, the less equity it holds the more assets it can hold that earn in excess of the cost of liabilities, and the larger are the returns that can be earned for owners. But the less equity the more at risk is the government's position as insurer of deposits, ceteris paribus, as a smaller loss on assets can make the bank insolvent. The tradeoff is then that the government requires that banks hold a minimum equity position (and also limits the types of assets banks can hold) to reduce its own risk and also the banks' potential moral hazard, whereas the government's insurance of bank deposits lowers further still the cost of bank liabilities (which offsets to some degree the cost of holding additional equity and also the deposit insurance).

Bank deposits (and 'near' deposits like savings accounts), as the cheapest liability, are then the preferred liability of banks (though larger banks hold fewer of them relative to other liabilities than smaller banks). There are other reasons for the preference for deposits (such as the fact that regulators prefer to see that deposits and similar liabilities are a significantly large percent of bank liabilities relative to, say, money market borrowings), but a bank's ability to grow its assets depends on its ability to earn profits - unless it issues more equity, which it normally prefers not to do and the best way to do this is to grow the bank's deposits. In other words, banks desire deposits because they are the most profitable source of liabilities.

\subsection{Defining reserve balances}

Some confuse reserve balances with other parts of a bank's balance sheet. A more complete accounting might reduce the likelihood of this happening in the future. First, Table 1 illustrates a simple, representative bank balance sheet. 
174 Review of Keynesian Economics, Vol. 1 No. 2

Table 1 Representative bank balance sheet

\begin{tabular}{lll}
\hline Assets & & Liabilities and equity \\
\cline { 1 - 1 } Vault cash & Deposits \\
Reserve balances & & Savings accounts \\
Deposits at other banks & & Money market accounts \\
Money market loans & & Time deposits \\
Securities & & Money market borrowings \\
Loans & & Long-term debt \\
Fixed assets & Loan-loss provision \\
& Preferred stock \\
& Common stock \\
& Retained earnings \\
\hline
\end{tabular}

Further, the following definitions are standard in bank accounting:

$$
\text { Reserves }=\text { Reserve Balances }+ \text { Vault Cash }
$$

Tier 1 Capital $=$ Equity $=$ Common Stock + Retained Earnings + Non-Cumulative Non-Redeemable Preferred Stock

Tier 2 Capital $=$ Long-Term Debt + Loan-Loss Provision + Cumulative Preferred Stock

Capital (Tier 1 and Tier 2) takes on losses from assets that are defaulted upon or not paid in full first. Loan loss provision is a before-the-fact 'set aside' of equity in anticipation of or as a buffer against future losses. Hybrid forms of debt and equity such as preferred stock count as Tier 2 capital if they are perpetual (no maturity date) and have cumulative dividend payments (all past dividends must be paid in full before a common dividend can be paid) and count as Tier 1 capital if they are noncumulative and non-redeemable (cannot be sold back to the issuer or converted to common shares prior to a stated redemption date).

Because both capital and loan-loss provisions are held in 'reserve' of losses on assets, both can be confused with bank 'reserves.' They are completely different, of course, the difference being akin to the difference between a household's net worth and its checking account. Both capital and loan-loss provisions (which, again, are a subset of Tier 2 capital) are balance sheet entries that do not represent actual cash or other balances owned by the bank. When banks issue stock, borrow long-term, or retain earnings, these do add to reserve balances, at least temporarily and by accounting identity (just as a household that borrows or receives a paycheck sees an addition to its money balances, at least temporarily). Bank reserves, as in equation (2.5), are composed of cash held by the bank or in its ATMs (balances in ATMs are considered vault cash), balances held in accounts at other banks, or balances held in accounts at the central bank. The latter are a bank's 'reserve balances.'

\subsection{Loans, reserve requirements, and withdrawals}

An important early step in understanding bank lending and endogenous money is to separate the act of creating a loan from the act of settling a payment that a loan enables. 
Table 2 T-account for bank loan

\begin{tabular}{ll}
\hline & Bank \\
\hline Assets & Liabilities and equity \\
${$\cline { 1 - 1 }$} }$ & 1. + Deposits \\
\hline
\end{tabular}

Table 3 Bank loan and money market borrowing to meet reserve requirements

\begin{tabular}{ll}
\hline & \multicolumn{1}{c}{ Bank } \\
\hline Assets & Liabilities and equity \\
\hline $1 .+$ Loan & 1. + Deposits \\
$2 .+$ Reserve balances & 2. + Borrowings (reserve requirement) \\
\hline
\end{tabular}

Table 4 Borrower's T-account

\begin{tabular}{ll}
\hline & Borrower \\
\hline Assets & Liabilities and equity \\
${$\cline { 1 - 1 }$} }$ & 1. + Loan \\
\hline
\end{tabular}

While it is true that often the two happen simultaneously - such as when a household uses a credit card to make a purchase - not understanding how the two are separate actions on a bank's balance sheet can lead to confusion. When a bank makes a loan, this increases the bank's assets by the amount of the loan and raises the deposits of the borrower by the same amount, as shown in the T-account in Table 2.

The newly created deposit, were it to stay on the bank's balance sheet, would result in added reserve requirements where applicable (several countries, including Canada, Great Britain, Australia, and New Zealand, have no reserve requirement), but even then reserve requirements are required to be held against deposits with a lag (of at least 17 days in the US). Regardless, a bank short of reserve balances to meet its requirement meets the requirement by borrowing in money markets, at the central bank's lending rate (usually a small amount above the central bank's target and also requiring collateral), or by receiving the deficient amount in its reserve account at the central bank's stated penalty rate. Money market borrowing - the most common method employed - is now added to the previous $\mathrm{T}$-account in Table 3. The T-account of the borrower is shown in Table 4.

If instead the borrower spends the proceeds of the loan to purchase goods, then this is equivalent to a withdrawal of the deposit as far as the bank is concerned. Note that in this case there is no need to borrow in money markets to meet reserve requirements, but the bank may borrow from another bank (often via previously established lines of credit) in the case of a withdrawal if it would otherwise be left with insufficient funds to carry a positive reserve account balance overnight or meet existing reserve requirements (where applicable). The T-accounts for the borrower's bank, borrower, spending recipient, and spending recipient's bank are shown in Table 5. 
Table 5 T-accounts for borrower's bank, borrower, spending recipient, and spending recipient's bank

\begin{tabular}{|c|c|}
\hline \multicolumn{2}{|c|}{ Borrower's bank } \\
\hline Assets & Liabilities and equity \\
\hline $\begin{array}{l}\text { 1. + Loan } \\
\text { 2. - Reserve balances } \\
\text { 3. + Reserve balances } \\
\text { Totals: + Loan } \\
\end{array}$ & $\begin{array}{l}\text { 1. + Deposits } \\
\text { 2. - Deposits } \\
\text { 3. + Borrowings (withdrawal) } \\
+ \text { Borrowings }\end{array}$ \\
\hline \multicolumn{2}{|c|}{ Borrower } \\
\hline Assets & Liabilities and equity \\
\hline $\begin{array}{l}\text { 1. + Deposits } \\
\text { 2. - Deposit } \\
\text { 3. + Goods purchased } \\
\text { Totals: + Goods purchased } \\
\end{array}$ & + Loan \\
\hline \multicolumn{2}{|c|}{ Spending recipient's bank } \\
\hline Assets & Liabilities and equity \\
\hline 1. + Reserve balances & 1. + Deposits \\
\hline \multicolumn{2}{|c|}{ Spending recipient } \\
\hline Assets & Liabilities and equity \\
\hline
\end{tabular}

In this example, the bank's loan is now offset on the liability side by borrowings in the money markets, which the bank acquired in order to meet the deposit withdrawal. As explained above, a bank's business model is to earn a spread on loans over overdrafts sufficient to provide owners with a competitive return on equity. The loan will require the bank to 'assign' a capital 'charge,' which is an additional opportunity cost to the bank beyond the cost of liabilities as the potential growth in assets is limited by available capital. As the spread on the loan is less than what the bank could have if it were to acquire deposits, this loan may not be sufficiently profitable with money market borrowings unless the bank does acquire deposits or charges a higher interest rate. At the same time, this is not necessarily the case, as larger banks (which operate more on economies of scale and earn a larger percentage of their revenues through noninterest income than smaller banks) regularly hold a significant percentage of their liabilities as money market borrowings.

The example also illustrates a fundamental tenet of banking and endogenous money the loan created the deposit, rather than being financed by the deposit or reserve balances. While the liquidity manager of the bank would be made aware of the potential withdrawal as the loan is being made and would secure additional funds for this purpose beyond pre-existing lines of credit with other banks if necessary, the decision to make the loan is unrelated aside from considerations regarding the interest rate on any such loan that the bank might not expect to eliminate later via the acquisition of more deposits. But this is a decision related to the profitability of the loan - and is made by 
a bank's lending committee according to the bank's strategy (which itself is set with regard to anticipated ranges of profitable growth in assets that is affected by anticipated ability to acquire deposits) or by loan officers authorized by executives to approve loans consistent with this strategy - not the quantity of deposits or reserve balances the bank has on hand prior to making the loan. Borrowings and reserve balances can always be had at some rate of interest; the question is whether or not this rate of interest is one at which the bank can make a profit that provides a sufficient return on equity.

The examples above also demonstrate that the actual uses for reserve balances are to meet reserve requirements (where applicable) and settle payments. Again, in either case, banks can always 'find' reserve balances at some rate of interest when needed or desired. Indeed, reserve balances actually may not be needed in any of the examples. Reserve requirements are met on a delayed basis, and the decision to create a loan and the total deposits a bank will be holding related to its reserve requirement can change considerably from monthly, weekly, and even daily (note that in the US reserve requirements are calculated as a percentage of end-of-day deposits averaged over a 2-week period less vault cash held by the bank over the same 2-week period; in the European Monetary Union, reserve requirements are calculated as a percentage of end-of-day deposits held for a month). Beyond deposit flows into and out of a bank, a bank's current customers might shift funds from deposits to savings, money market accounts, or time deposits (all of which are non-reservable). Further still, banks themselves have been able to reclassify some of their customers' deposits as money market accounts temporarily to avoid reserve requirements (Anderson and Rasche 2001).

That the bank might require reserve balances to meet a withdrawal is even less certain. If the spending recipient and the borrower use the same bank, then the bank will simply debit the borrower's account and credit the recipient's. Even if they use different banks, daily flows into and out of a bank's reserve account are considerable, and the bank may not actually end the day with a net outflow (and even in that case, it might already have sufficient balances to not end the day with a negative balance or short of its desired level for meeting reserve requirements). Further, many payments settle in local or national netting payments systems for which a bank will only see its account debited at the close of business in the event of a net outflow after taking into account all transactions for the day. During the day itself, in the US case a bank will receive an automatic overdraft if it sends a payment that would otherwise leave its account with a negative balance; the Federal Reserve (hereafter, the Fed) guarantees that any payment sent on Fedwire (the Fed's gross payment settlement system - as opposed to net settlement) will be completed regardless of the balances in the bank's account at the time it sends the payment. The Fed does 'encourage' banks to go to money markets and clear an overdraft in its reserve account by the end of business by setting a very high penalty for an uncollateralized overdraft and a smaller but still significant penalty rate for collateralized borrowing at the discount window.

Overall, at the level of the individual bank, the act of lending is not deposit or reserve constrained. Banks do want deposits, but that is because these are the least expensive liability (and because regulators frown upon not having deposits as a significant percentage of total liabilities) for pursuing the bank's traditional business model of leveraging its equity ten or more times over to earn a significant return on equity against a slight (relative to non-financial businesses) return on assets. The act of making a loan is separate from the act of settling a payment that might result from the loan; from the bank's perspective, a customer that uses proceeds from a loan to make a purchase is making a withdrawal of deposits created by the loan. Banks use reserve balances to meet reserve requirements to settle payments 
made by their customers, and these are always available at some rate of interest in money markets; the rate of interest a bank can acquire these balances will affect the profitability of a loan and thus the bank's decision on whether or not to lend at a particular rate, but the quantity of reserve balances a bank is holding at the time it makes a loan is not a consideration in approving the loan. Finally, it is worth adding here that in the age of securitization, banks obviously make loans that they then sell, in which case there is a reserve inflow that will enable the bank to pay off any money market borrowings that might have been incurred when the loan was made and the proceeds were spent by the borrower.

\section{CENTRAL BANKS AND ENDOGENOUS MONEY}

\subsection{The unavoidable responsibility to the payments system and the necessity of an interest rate target}

According to the Fed's data, average daily dollar volume of payments settled via Fedwire the Fed's real-time gross settlement system - was 17 percent of GDP in 2011 (Federal Reserve 2012). This is a fairly typical percentage that one sees across countries, as Fullwiler (2008) shows. In other words, within 5 to 10 business days, the value of payments settled using central bank balances eclipses that country's annual gross domestic product (GDP). This does not account for a far larger value of payments that are settled on various netting systems (say, for fixed income, equity, and money market transactions) and then are settled on a netted basis using reserve accounts. Put simply, the smooth functioning of the national payments system is indispensable to any national economy, and the central bank is ultimately responsible for ensuring its operations continue without disruption. Whereas historically economic research, models, and textbooks focused on reserve requirements when analysing monetary policy, the better starting place is the modern central bank's role in the national payments system (Fullwiler 2003).

What this means is that the central bank's provision of reserve balances at some price is ultimately non-discretionary. While in some countries - as in earlier eras central banks provide this through direct lending to banks (the overdraft system as described in Lavoie 2003), in the US it has been done (prior to fall 2008) through direct intraday overdrafts for banks and then provision of sufficient aggregate reserve balances via repurchase agreements (that is, temporary open market operations with primary dealers through securitized lending) so that banks can clear the overdrafts by the end of business via private money markets and the federal funds rate can remain at roughly the Fed's target throughout. As Mehrling (2011) explains,

\footnotetext{
When individual banks need money [that is, reserve balances] to meet their commitments at the daily clearing, they usually raise it from other banks in the wholesale money market. And when the banking system as a whole needs money, that money is usually raised by selling security holdings into liquid markets. Both channels are backstopped ultimately by the Fed's commitment to stabilize the federal funds rate around a chosen target, and by its intervention to make good on that commitment by lending in the Treasury repo market. (pp. 26-27)
}

The greater complexity of the latter approach relative to direct lending to banks made it difficult for many to recognize that the two approaches were not different fundamentally in terms of the underlying nature of the central bank's operations; both resulted in the elastic supply of reserve balances at the central bank's target rate, and in either case there was no other choice to make without threatening the smooth functioning of the payments system. 
As Fullwiler (2003) explains, reserve requirements do not alter this 'underlying nature' of central bank operations. Without reserve requirements, banks desire to hold overnight only that quantity of balances they believe they need for settling payments. The demand for reserve balances is roughly vertical at this quantity, though the quantity can change from day to day, as there is no reason to hold more or less than this quantity. Loans create deposits and more reserve balances do not increase the ability to lend. With reserve requirements, banks desire to hold overnight only that quantity of balances they believe they need for settling payments and meeting reserve requirements. The demand for reserve balances is roughly vertical at this quantity by the end of the maintenance period. Banks have no use for more or less than this quantity. If the central bank does not supply the quantity banks demand at its target rate, in either scenario the result is for the interbank rate to rise or fall until reaching the central bank's penalty or remuneration rate. This is a de facto interest rate target.

Figure 1 illustrates interbank targeting in the interbank market with no reserve requirements. The demand for reserve balances $\left(D_{\mathrm{RB}}\right)$ is horizontal at both the central bank's penalty and remuneration rates ( $i_{\text {penalty }}$ and $i_{\text {remuneration, }}$, respectively), as no bank would borrow in the interbank market at a rate higher than the penalty rate or lower than the remuneration rate. The demand curve is shown as roughly vertical between these rates at the quantity of reserve balances banks desire to hold at the target rate $\left(\mathrm{RB}^{*}\right.$ and $i_{\text {interbank }}{ }^{*}$, respectively). More than a trivial deviation from this quantity sends the interbank rate to the penalty or remuneration rates, which is itself de facto interest rate targeting.

Figure 2 (essentially equivalent to Figure 3 in Lavoie 2010) shows interest rate targeting in the interbank market with reserve requirements. The differences from Figure 1 are the kinks in the $D_{\mathrm{RB}}$ line because the maintenance period for meeting reserve requirements is more than a day in practice. In other words, banks can average across several days ( 2 weeks in the US; a month in the European Monetary Union) their reserve balances held to meet reserve requirements. Balances held can then be above the reserve requirements on some days to offset being below on other days. This flattens the $D_{\mathrm{RB}}$ line for a range of reserve balances. It is clear from Figure 2 that the true role of reserve requirements for modern central banks is to aid the task of achieving the interest rate target, as the quantity RB* does not need to be estimated as precisely. This flatter $D_{\mathrm{RB}}$ section holds until the end of the maintenance period draws near, at which time the flatter portion shrinks; by the end of the maintenance period $D_{\mathrm{RB}}$ is again as

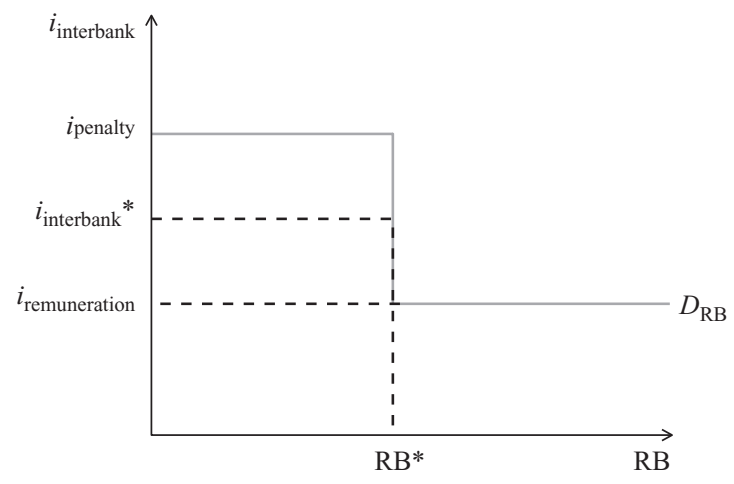

Figure 1 Interest rate targeting in the interbank market with no reserve requirements 
180 Review of Keynesian Economics, Vol. 1 No. 2

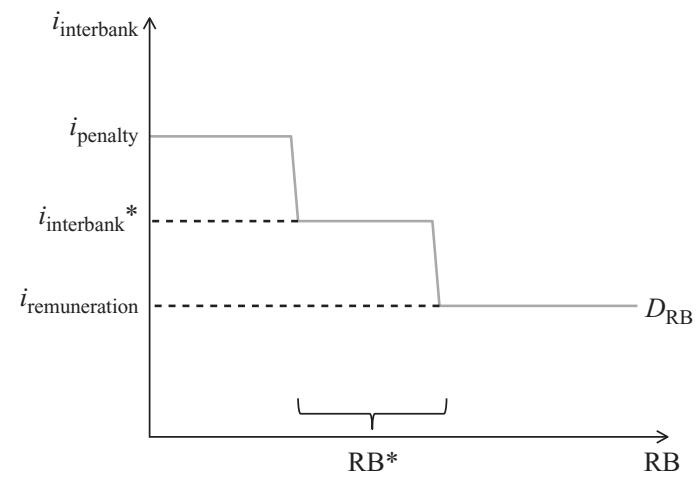

Figure 2 Interest rate targeting in the interbank market with reserve requirements

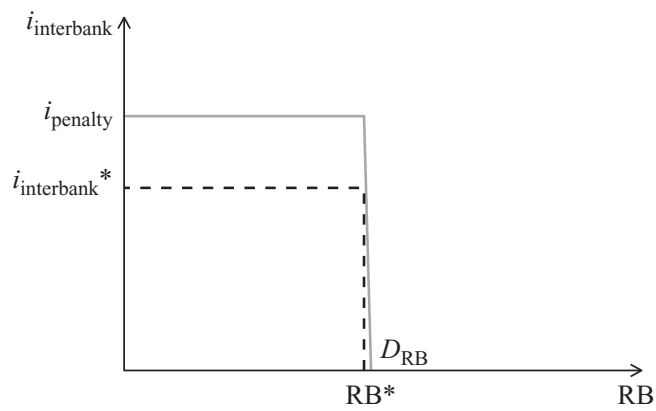

Figure 3 Interest rate targeting for the Fed prior to IOR

shown in Figure 1, albeit probably at a higher level of RB*, as banks can no longer average their balances across days. Consequently, by the end of the maintenance period, just as without reserve requirements, banks have no use for a non-trivial deviation from RB*, and such a deviation is again simply de facto targeting of the interest rate at $i_{\text {penalty }}$ or $i_{\text {remuneration. }}$ It is clear, for instance, from Fed research regarding the 1979-1982 period of reserve targeting that the Fed understood that it could not directly target reserve balances and so it instead attempted - with little success in the end, it should be noted - to indirectly target them via more frequent changes in the federal funds rate (Lang 1980; Volcker 1980; Meulendyke 1988).

\subsection{The offsetting and accommodating nature of the central bank's operations}

The necessity for the central bank's operations to accommodate banks' needs to settle payments and meet reserve requirements while achieving the target rate exists because banks in the aggregate cannot alter the quantity of reserve balances. Recalling Mehrling's quote above, individual banks can borrow and lend in money markets, but the banking system as a whole can only affect the distribution of total reserve balances, not the quantity. This is obvious - as a liability on the central bank's balance sheet, the aggregate quantity of 
Table 6 T-accounts for bank $A$, bank $B$, and the central bank for an interbank loan from bank $A$ to bank $B$

\begin{tabular}{|c|c|}
\hline \multicolumn{2}{|r|}{ Bank A } \\
\hline Assets & Liabilities and equity \\
\hline $\begin{array}{l}\text { 1. + Loan to bank B } \\
\text { 2. - Reserve balances }\end{array}$ & No change \\
\hline \multicolumn{2}{|r|}{ Bank B } \\
\hline Assets & Liabilities and equity \\
\hline 1. + Reserve balances & 1. + Borrowings from bank A \\
\hline \multicolumn{2}{|r|}{ Central bank } \\
\hline Assets & Liabilities and equity \\
\hline No change & $\begin{array}{l}\text { 1. - Reserve balances bank A's account } \\
\text { 2. + Reserve balances bank B's account }\end{array}$ \\
\hline
\end{tabular}

reserve balances can only change when something else besides reserve balances on its balance sheet changes. Table 6 illustrates this fact of double-entry accounting.

Given that the operating target is necessarily an interest rate and that the quantity of reserve balances in the aggregate only changes when something else on the central bank's balance sheet changes, the central bank's operations necessarily accommodate the demand for reserve balances at the target rate (Fullwiler 2008; Lavoie 2010). The scope of possible shifts in banks' desired holdings is a result in itself of the central bank's method of setting the interest rate. The greater confidence banks have that they will not have to visit the central bank's standing facilities to borrow at the penalty rate to clear an overdraft from payment outflows, the less they will hold in excess as a buffer against this possibility. In Canada, for instance, banks have complete certainty they will not end the day in overdraft; this coupled with no reserve requirements enables Canadian banks to hold 0 reserve balances in the aggregate overnight. Obviously, with reserve requirements added, assuming they are not trivial, banks will desire still more reserve balances at the target rate, though how many depends on several factors (Fullwiler 2008). In the US, for example, prior to the mid-1990s, reserve requirements were economically significant and banks held more than $\$ 30$ billion in reserve balances. The proliferation of retail sweep accounts enabled banks to avoid reserve requirements to the degree that they became essentially voluntary by the end of the 1990s, at which time banks held a bit more than $\$ 10$ billion in reserve balances (which suggests this was near the quantity banks in the US would have held overnight as a buffer against overdrafts in the absence of reserve requirements) (Anderson and Rasche 2001; Fullwiler 2003).

While accommodating swings in banks' demand for reserve balances (where applicable - in Canada the demand for overnight balances is always 0), central bank operations offset changes to their balance sheets that are not consistent with banks' desired holdings of reserve balances at the targeted interest rate (Fullwiler 2008; Lavoie 2010). By far the most important of these changes is the growth in currency; as described above, banks purchase currency to hold as vault cash to meet 
customer withdrawals via reserve accounts. As currency grows, this drains reserve balances, which central banks then replenish via open market operations (permanent or repo) or loans to banks. Another important change arises from flows to/from the treasury's account at the central bank, which is debited when the government spends via crediting of bank reserve accounts and credits to the deposit accounts of recipients. For the most part, central banks are spared from dealing with anything but some minor daily swings in the treasury's account (though some treasuries - such as the US Treasury - attempt to offset these, too, via transfers and withdrawals to/from correspondent accounts at private banks) since most countries require their treasury rather than their central bank to issue bonds that drain reserve balances as an offset to the addition to reserve balances a deficit brings.

The net effect of the accommodating and offsetting nature of the central bank's operations is that there is no role for price discovery in the overnight market where a central bank sets a target rate. As Martin and McAndrews (2008) put it,

The cost of reserves, both intraday and overnight, are policy variables. Consequently, a market for reserves does not play the traditional role of information aggregation and price discovery. In fact ... many demand-management features determined by central bank policy are intended to dampen variability in the market for reserves. (p. 1)

In other words, deviations from this target rate simply suggest that the central bank has for whatever reason chosen not to accommodate swings in the demand for reserve balances or to offset fully changes to its balance sheet. This is not the private 'market' engaging in price discovery; it is instead the policymaker setting a rate and then determining how precisely to achieve it. As above, leaving banks short of reserve balances to settle payments or meet reserve requirements will raise the rate to the penalty or lending rate, whereas leaving banks in an undesired excess position will lower the rate to the remuneration rate. Note further that the central bank could very precisely achieve its target rate simply by narrowing the corridor between its lending rate and the remuneration rate. For instance, setting the two at, say, five basis points above and below the target rate would effectively guarantee that the interbank rate would not move outside this range. Similarly, changing the target rate can simply be achieved by announcing changes to all three rates (lending, target, and penalty rates) in tandem; given the roughly vertical demand for reserve balances, banks cannot 'do' anything with more reserve balances and require at least enough of them to settle payments and meet reserve requirements for the target rate to be achieved. As such, it is not surprising that researchers have not found evidence of a liquidity effect associated with changes to the central bank's target rate (see Friedman and Kuttner 2010 for recent empirical evidence and Fullwiler 2003 for the operational details that explain why there is no liquidity effect).

\section{INTEREST ON RESERVE BALANCES - IT'S LESS SIGNIFICANT THAN YOU THINK}

Fullwiler (2005) argued that interest on reserve balances (hereafter, IOR) was 'more significant than you think.' The point there, however, was not that IOR is important to the transmission of monetary policy, but rather that (1) understanding IOR within a corridor system (as in Figure 1, where the remuneration rate is the rate of IOR) was an appropriate general approach to understanding central bank operations, and (2) understanding IOR in the context of government deficits without bond sales was 
an appropriate general approach to understanding government debt operations. In other words, what was 'more important' was the alteration in one's mental model that results from understanding how IOR works as a general case. Whether or not the central bank actually institutes IOR was not the point, and was not necessarily promoted in the paper. But the paper clearly suggested that, were IOR to be implemented, this would significantly simplify the Fed's operations. Several other researchers - many associated with the Fed - also noted that IOR would enhance the effectiveness of the Fed's interest-rate-targeting tactics as it accommodated banks' needs to settle payments (for example, Goodfriend 2002; Lavoie 2005; Lacker 2006; Anderson 2008; Keister et al. 2008; and Ennis and Keister 2008).

In the US, the Fed was authorized in 2006 to pay IOR beginning in 2011. As noted, IOR simply makes it easier for the central bank to achieve an interest rate target. Consider Figure 3 in comparison to Figure 1 above - in the US prior to IOR, the Fed had a penalty rate to halt a rise in the interbank rate in the event of too few reserve balances circulating, but no ability to halt a fall if banks held reserve balances in excess of the target rate. With a roughly vertical demand for reserve balances - given that banks were meeting most reserve requirements through vault cash and mostly used reserve balances to settle payments (Figure 1 in Lavoie 2010 shows this for the case in which required reserves are significant - the Fed would have to accurately estimate the demand for reserve balances to achieve a target rate. Beginning in August 2007, this became more difficult as the Fed's 'Credit Easing' operations that were providing additional liquidity to money markets through a variety of new standing facilities needed to be offset by reverse operations to avoid a zero-percent overnight rate. Volatility in the overnight rate increased substantially due to this and also greater swings in the demand for reserve balances as other money markets experienced severe stress. The Fed reduced its penalty rate from 1 percent above the target rate eventually to 0.25 percent above the target rate by Spring 2008 to limit volatility; in May 2008, the Fed requested the authority to pay IOR before the 2011 date but was denied by Congress.

The quick increase in reserve balances through standing facilities from around $\$ 20$ billion to around $\$ 800$ billion following Lehmans' failure could not reasonably be offset by reverse operations (the Fed did not own enough securities at the time, at any rate). As Congress moved up the date for IOR to October 2008, this enabled the Fed to achieve a positive target rate with large quantities of excess reserve balances well beyond banks' desired levels, at least in theory. This is shown in Figure 4 (essentially the same as Figure 4 in Lavoie 2010), as the target rate $\left(i^{*}\right)$ is set equal to IOR $\left(i_{\text {remuneration }}\right)$ and the quantity of reserve balances in circulation $\left(\mathrm{RB}_{a}\right)$ is significantly greater than the quantity banks desire to hold at the target rate $\left(\mathrm{RB}^{*}\right)$. Setting IOR equal to the target rate thus enables a positive interest rate target from basic supply and demand analysis of a price floor in the presence of excess quantity supplied. (In practice, the federal funds rate has traded below IOR since some institutions with reserve accounts are not allowed to earn interest; but this is a quirk in the way IOR is implemented in the US, not a refutation of the above-cited literature on IOR.)

According to the traditional money multiplier model, such a large increase in reserve balances should raise the money supply as banks lend out newly acquired excess reserves. But as the endogenous money approach predicts, the rise in reserve balances from Credit Easing, then Quantitative Easing 1 (hereafter, QE1, in which the Fed purchased $\$ 1.75$ trillion in securities, most of them mortgage-backed securities, though much of this replaced the reserve drain from Credit Easing loans being paid back as the crisis subsided but the recession continued), then Quantitative Easing 2 


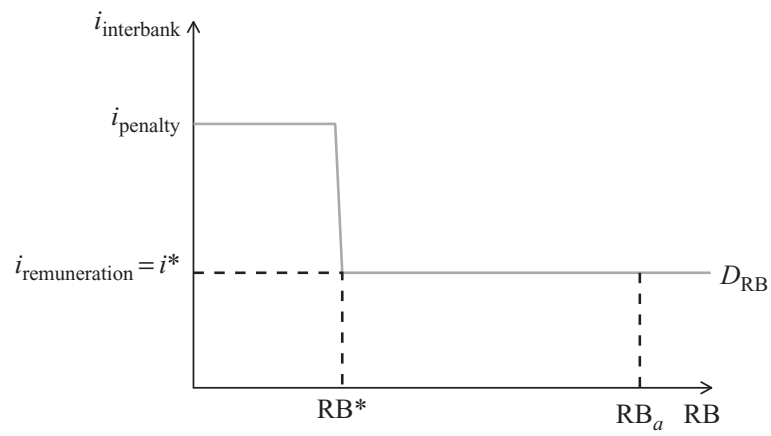

Figure 4 Interest rate targeting and IOR with large excess reserves

(hereafter QE2, in which the Fed purchased $\$ 600$ billion in Treasury securities), and now Quantitative Easing 3 (hereafter, QE3, in which the Fed plans to purchase $\$ 40$ billion in mortgage-backed securities per month until the economy performs substantially better) from a starting level below $\$ 20$ billion to now a bit below $\$ 2$ trillion has not been accompanied by substantially increased lending, real GDP growth, or inflation.

Whereas this might have been a time for economists to consider that perhaps the money multiplier model and the Quantity Theory of Money have causation wrong, instead the lack of impact from increased quantities of excess reserves is often blamed on IOR. The narrative here is often along the lines of the following: when reserve balances earn interest, this provides banks with an alternative to lending the reserve balances, or (where it is already recognized that banks do not lend reserve balances except in the federal funds market to other banks) an opportunity cost to making a loan; as such, the money multiplier model does not hold under IOR (see, for instance, Keister and McAndrews 2009 or Martin et al. 2011, and also the discussion and critique in Lavoie 2010). A related view is that the interest earned on 'money' (that is, reserve balances) is roughly equal to the interest earned on 'bills' (that is, Treasury bills), making the two perfect substitutes and thereby putting the economy in a position like the Keynesian 'liquidity trap' where no quantity of excess 'money' balances can induce spending (for example, Krugman 2011).

But this cannot be true. Under normal circumstances, without large quantities of reserve balances, banks already have the opportunity to purchase Treasury bills (hereafter, T-bills) that earn roughly the target rate rather than make loans. To illustrate this, consider a bank that instead of making a loan chooses to purchase T-bills, as in Table 7. Here, the bank first purchases a T-bill via overdraft at the Fed, which illustrates the endogenous nature of bank balance sheet expansion in this case (and note that T-bills do not incur a capital charge for the bank). The bank clears the overdraft via money market borrowings and is ultimately left with a T-bill on the asset side offset by money market borrowings on the liability side. If IOR at the target rate were an opportunity cost restricting bank lending, then one would similarly expect that, even without IOR, banks would be holding T-bills instead of lending, as they are equivalent in terms of default risk (none) and financial return (essentially the Fed's target rate for both). But banks do not hold T-bills instead of lending, obviously, aside from holding them as secondary reserves prior to the proliferation of modern liability management (in which case they were held for liquidity purposes, rather than as an alternative to lending). 
Table 7 T-accounts for bank investing in T-bills

\begin{tabular}{|c|c|}
\hline \multicolumn{2}{|c|}{ Step 1: T-Bill purchased via Fed overdraft } \\
\hline Assets & Liabilities and equity \\
\hline $\begin{array}{l}\text { 1. + T-bill } \\
\text { 2. - Reserve balances } \\
\text { 3. + Reserve balances } \\
\text { Totals: + T-bill }\end{array}$ & $\begin{array}{l}\text { 3. + Overdraft from Fed } \\
+ \text { Overdraft from Fed }\end{array}$ \\
\hline \multicolumn{2}{|c|}{ Step 2: Borrowing in money markets to clear Fed overdraf } \\
\hline Assets & Liabilities and equity \\
\hline $\begin{array}{l}\text { 4. + Reserve balances } \\
\text { 5. - Reserve balances } \\
\text { Totals: + T-bill }\end{array}$ & $\begin{array}{l}\text { 4. + Borrowings } \\
\text { 5. - Overdraft from Fed } \\
+ \text { Borrowings }\end{array}$ \\
\hline
\end{tabular}

In the real world, banks do not hold large quantities of T-bills because they cannot make sufficient profit on them relative to liabilities. In Table 7, the bank borrowing in the money market is probably paying more on its liabilities than it is earning on T-bills. Potentially the bank can earn a profit if it can acquire deposits to replace the money market borrowings, but even in that case the spread may not be large enough; note that in the current environment many banks have increased fees on ATM usage and so forth, in part to offset lost profits from holding so many reserve balances earning only 0.25 percent more than the lowest cost liabilities - deposits could possibly cost. Whereas in the early 1990s banks did hold longer-term Treasuries that earned several percentage points more than short-term liabilities to restore profitability instead of engaging in more risky lending, T-bills would virtually never enable this. Overall, the view of IOR as a new opportunity cost to lending misses a fundamental point of bank management, which is that any risky financial asset acquired must earn at least the risk-free rate of return because banks always have the option of holding T-bills; since IOR is not an economically significant alternative to a T-bill, it cannot be any more of an opportunity cost to lending than T-bills already are in the absence of IOR. As Fullwiler (2005, p. 547) argues, the transmission mechanism for monetary policy is the same with or without IOR. The slowdown in bank lending is because banks do not view current opportunities to do so as profitable once the risks are considered, rather than because banks hold interest-earning reserve balances.

Lastly, an important internal contradiction is that it is not operationally possible for a central bank to both achieve a positive interest rate target and leave substantial undesired excess reserves circulating without setting IOR equal to the target rate. Again, this is 101-level economics as shown in Figure 4: an increase in supply requires a price floor in order to support a price above that which the market would set on its own. And in this case the market's price would obviously be 0 . Thus, even within the context of their own argument, the money multiplier and quantity theory of money (due to falling velocity) cannot be invoked. In other words, if economists believe that the money multiplier and quantity theory of money do not hold when IOR is equal to the target rate (or, roughly equivalently, when 'money' earns the same as 'bills') and if a large excess of reserve balances can only be supplied at a positive interest rate target if and only if IOR is set equal to the target rate, then it can only be that the money multiplier and quantity theory of money can never be applicable in 
instances in which there are large quantities of excess reserve balances supplied exogenously by the central bank beyond the quantities desired by banks at the target rate.

\section{HELICOPTER DROPS OF MONEY ARE FISCAL OPERATIONS}

QE or quantitative easing - the outright purchase of securities by the central bank in the hope of stimulating the economy - is heralded as a way to deal with the inability to reduce interest rates further once the zero-bound is reached. From an endogenous money perspective, as explained, QE represents an inapplicable view of banking and credit based upon the money multiplier model (Lavoie 2010). Since banks require neither reserve balances nor deposits to make loans, at least operationally, adding to the stock of either does not in itself stimulate the economy. An understanding of the endogenous money perspective would have led one to correctly predict that the outcome of quantitative easing would simply be a reduction in the velocity of money rather than raising real or nominal GDP. As mentioned, with endogenously created credit, credit and deposits come into existence with a decision to spend more than income, combined with a lender's belief that the borrower is creditworthy and the loan will be profitable, not as a result of banks holding more reserve balances.

But there is another view of QE that is not necessarily related to the money multiplier model but rather to a direct inducement to spend excess money balances created by the operations. Much of the economics profession, and certainly the financial press in general, equate quantitative easing and so-called 'helicopter drops of money'. The latter was originally popularized by Milton Friedman, who argued that the central bank could increase the money supply much as if it were dropping money from helicopters. From basic analysis of the balance sheets of both actions, this is in fact not the case, as the two are quite different. Tables 8 and 9 show helicopter drops of currency and credited deposits, respectively, through central bank and recipient balance sheets. Of most significance in both cases is that helicopter drops increase the equity or net worth of the recipients. The additional 'money,' in other words, is in fact income that adds to the recipients' income and thus saving, unless the recipients choose to spend an amount equal to the additional income. In the latter case, the additional money would still have increased the private sector's net saving (or net acquisition of financial assets) overall.

By way of comparison, Tables 10 and 11 illustrate QE carried out as purchases of government securities from bank dealers and non-bank dealers, respectively (the Fed's QE operations are exclusively with primary dealers). Unlike helicopter drops, QE does

Table 8 Helicopter drop of currency

\begin{tabular}{|c|c|}
\hline \multicolumn{2}{|c|}{ Central bank } \\
\hline Assets & Liabilities and equity \\
\hline No change & $\begin{array}{l}\text { 1. + Currency } \\
\text { 2. - Equity }\end{array}$ \\
\hline \multicolumn{2}{|c|}{ Currency recipient } \\
\hline Assets & Liabilities and equity \\
\hline 1. + Currency & 1. + Equity \\
\hline
\end{tabular}


Table 9 Helicopter drop of credited deposits

\begin{tabular}{|c|c|}
\hline \multicolumn{2}{|c|}{ Central bank } \\
\hline Assets & Liabilities and equity \\
\hline No change & $\begin{array}{l}\text { 1. + Reserve balances } \\
\text { 2. - Equity }\end{array}$ \\
\hline \multicolumn{2}{|c|}{ Deposit recipient } \\
\hline Assets & Liabilities and equity \\
\hline 1. + Deposits & 1. + Equity \\
\hline
\end{tabular}

Table 10 QE operation with a bank dealer

\begin{tabular}{lc}
\hline \multicolumn{2}{c}{ Central bank } \\
$\frac{\text { Assets }}{\frac{1 .+ \text { Treasuries }}{\text { Bank dealer }}}$ \\
$\begin{array}{l}\text { Assets } \\
\begin{array}{l}\text { 1. + Reserve balances } \\
\text { 2. - Treasuries }\end{array}\end{array}$ \\
\hline
\end{tabular}

Table 11 QE with a non-bank dealer

\begin{tabular}{|c|c|}
\hline \multicolumn{2}{|c|}{ Central bank } \\
\hline Assets & Liabilities and equity \\
\hline 1. + Treasuries & 1. + Reserve balances \\
\hline \multicolumn{2}{|c|}{ Primary dealer } \\
\hline Assets & Liabilities and equity \\
\hline $\begin{array}{l}\text { 1. + Deposits } \\
\text { 2. - Treasuries }\end{array}$ & 1. No change \\
\hline \multicolumn{2}{|c|}{ Primary dealer's bank } \\
\hline Assets & Liabilities and equity \\
\hline 1. + Reserve balances & 1. + Deposits \\
\hline
\end{tabular}

not raise the equity or net worth of the non-government sector. Put into financial ratio terms, helicopter drops reduce the recipient's leverage, whereas QE keeps leverage the same by simply swapping the assets of the dealer. If the non-government sector decides to increase spending, this would be an increase in spending out of pre-existing income rather than an increase in spending out of increased income as would occur 
with a helicopter drop. Increased spending following QE results either in no change to the spender's leverage (assets/equity) - cash balances reduced and purchases added to asset side - or an increase via added debt to finance spending. On the other hand, spending out of increased income swaps the assets of the spender (cash for whatever is purchased), and does not raise the spender's leverage that was reduced by the increase in income. In the aggregate, spending as a result of QE (out of existing income or via debt) will raise the total leverage of the private sector, if not outright (in the case of increased spending only out of current income) then as the spending raises incomes and thus taxes are paid. Spending as a result of a helicopter drop offsets to some degree the reduction in leverage, but a net reduction in leverage remains (assuming the marginal propensity to consume is not greater than 1). In other words, stimulating the economy via a helicopter drop will normally reduce the private sector's leverage, but doing so via QE will do the opposite.

To understand the significance of this distinction, recognize that Tables 10 and 11 represent traditional monetary policy operations, albeit done such that reserve balances far exceed what banks would desire to hold at the target rate. The other potential operation by the central bank would be direct lending or repos with dealers (which are also a loan). Obviously, lending to the private sector does not raise the equity or net worth of the private sector, but rather raises the latter's leverage. Fiscal policy operations via government deficits, on the other hand, do increase the net worth or equity of the non-government sector much as is occurring in Tables 8 and 9. A bond sale by the Treasury is simply the reverse of a bond purchase by the central bank from the nongovernment sector's perspective, and since (from Tables 10 and 11) the latter does not add to net worth or equity, the bond sale obviously does not subtract from it. But the deficit itself is an increase in the non-government sector's income directly, either through spending that adds to the income of recipients or reduced taxes that increase the after-tax income of taxpayers.

In other words, helicopter drops are fiscal deficit-spending operations, not monetary policy operations. Another way to think of the difference between helicopter drops and QE is to consider the difference between (a) receiving a \$20 000 deposit courtesy of the government and (b) having \$20 000 of one's financial portfolio converted from bonds to deposits. Clearly no individual should rationally consider these two to be equivalent, because they are not. But the excess money balances or the 'hot potato effect' view argues that (b) should increase spending just as (a) would, ignoring the differences between the two with regard to an increase in income versus a portfolio shift of existing wealth. This is not unlike believing that spending will increase if private banks encourage customers to hold deposits rather than money market deposit accounts through fees and such, and then spending will decrease if they instead reverse course and encourage the opposite. Indeed, the fact that individuals can easily and costlessly transfer balances between savings-related accounts and deposits is precisely why the 'hot potato effect' does not actually occur; deposits do not spend themselves, after all.

As a bit of a digression, this ability to costlessly convert is also present with regard to holding currency versus deposits. The latter are guaranteed by the government to convert to currency at par value. Consequently, helicopter drops of currency that result in excess cash balances are not operationally possible. If private agents are holding excess cash, they convert these to deposits, and then to savings, if desired. Banks end up with more vault cash and sell this back to the central bank in exchange for reserve balances. As always, the quantity of currency circulating is endogenously set by the portfolio preferences of the private sector. The only portion of the monetary base that the central bank can set directly is the quantity of reserve balances, and even then only if it is willing to pay interest on reserve balances at the target rate. 
As a qualification, it is possible for QE to function with some of the qualities of helicopter drops if purchases of Treasuries or private debt increase their price relative to the issue price or if the face value of the private debt purchased is later reduced or defaulted upon. The latter would reduce the central bank's equity while reducing the private sector's net debt position. However, this is not the intent of these operations. The Fed has set up QE1 and QE3 to minimize default risks to its private debt purchases since a significant reduction of its equity could bring political difficulties, even if operationally it would not affect its position as the monopoly supplier of reserve balances. QE3, like QE1, is intended to reduce mortgage rates at the point of the loan by adding liquidity to the secondary market for mortgage-backed securities, not to create a capital gain for the dealer that sells the security to the Fed. And QE1 and QE2 were actually structured such that the Fed's purchases would have little total effect on market rates (though this changes in QE3, but again not via a capital gain to the dealer). Estimates of the effects of QE1 and QE2 on respective market rates were in the range of 25 basis points (see for example Gagnon et al. 2010; and Hamilton and Wu 2011) - and even that is perhaps a stretch in the case of QE2, given that rates actually increased on longer-term Treasuries, possibly as a result of the general public's view that $\mathrm{QE}$ is inherently inflationary and would require the Fed to raise rates sooner. At any rate, these estimates are hardly economically significant in the sense that a 0.25 percent change in either is not going to have much of an effect on the broader economy. Even doubling the effect would not be overly significant in the current context; does anyone really believe that cutting the mortgage rate from 4 percent to 3.5 or even 3.25 percent is sufficient to end the deepest recession since the Great Depression?

To be fair, those promoting the 'hot potato effect' view do assume that central bank purchases of financial assets would be significant enough to raise prices and thus reduce yields in an economically significant way, which would then ultimately lead to spending on goods and services as agents balance marginal 'returns' from consumption with reduced returns to financial wealth. (This is one reason why they have been critical of the Fed's approach to this point.) There are two important points to make here. First, if such purchases are significant enough to affect the prices of the financial assets being purchased by the central bank, this is an increase in the private sector's equity through central bank operations, via a capital gain, which is essentially income when realized and thus an act of fiscal policy. However, these transfers to financial institutions with whom the Fed trades are probably far less stimulative than the same-size transfers to households or direct purchases of goods and services might be. Second, promoters of these central bank operations are interested not in these income or fiscal effects - which, again, probably would have small fiscal multipliers at any rate - but rather the effects of the greater quantity of 'money' (given their belief that deposits spend themselves) and lower yields for stimulating spending on a greater scale. In other words, if these operations 'work,' the stimulus effect would be through either a decision to spend more out of existing income following a portfolio shift to more 'money' balances and/or a decision to borrow in order to spend more out of existing income, not any potential (and likely very minor) fiscal effects of the operations. Thus, were QE to work, it would do so almost entirely through additional private sector leverage, not additional income or net financial wealth for the sector.

To summarize and conclude this section, monetary policy stimulus operates via (a) reducing interest rates and thus encouraging agents to borrow or otherwise spend more than their current income - that is to say, increase leverage - and/or (b) raising financial asset prices through QE or related measures so much that it encourages spending via wealth effects. Stimulus method (a) works exclusively through increased private sector leverage, while (b) works almost exclusively through leverage. In the 
case of (a), the effect is offset at least to some degree by the facts that (i) savers have seen their incomes reduced by both lower overall interest rates and (ii) Treasury purchases by the central bank reduce the term structure of the national debt and replace bond interest earnings of the non-government sector with the lower rate paid on reserve balances. In the case of (b), the quantity of operations necessary to generate a macroeconomically large effect on financial asset prices probably threatens to induce asset price bubbles somewhere in the financial system, whether as a result of the central bank's own purchases or as a result of speculative actions by financial institutions related to expectations of the effects of the central bank's actions. Aside from interest rate or supposed portfolio shift effects that necessarily operate to allow additional leverage to 'work,' QE-related asset purchases are at best a weak and indirect fiscal action, and at worst can be the impetus for asset price inflation. In short, monetary policy stimulus, because it operates almost entirely through raising the leverage of the non-government sector even in the case of QE, is a stark contrast to fiscal policy that by definition raises the income and net financial wealth of the private sector. This does not by itself suggest monetary policy is inappropriate; it does, however, mean that policymakers and economists should be more detailed in their understanding of the private sector balance sheet effects of different approaches to the macroeconomic policy mix and be sure that policy actions are consistent with desired private sector balance sheet outcomes. To date this has not been the case.

\section{ENDOGENOUS MONEY AFTER THE CRISIS AND RECESSION}

There are several key lessons from endogenous money that should inform future macroeconomic theory and policymaking. These are already well-known and have been voiced eloquently by numerous others both before and after recent events. To begin, modern endogenous money banking systems are not fractional reserve systems. As described above, reserve requirements - where they exist - do not limit banks in the creation of credit and money. The modern purpose of reserve requirements is to flatten the demand for reserve balances and make it easier for central banks to achieve their targeted interest rates, not to constrain bank lending and money creation. Because of this, there is no fixed 'pool' of funds that limits bank lending as in the ubiquitous but deeply flawed loanable funds model. Credit creation and banks matter, as banks are not simply intermediaries taking deposits from savers and lending the funds to borrowers. Credit and money are created endogenously, out of thin air, independent of prior deposits, at the initiative of a borrower deemed creditworthy and in the context of a loan deemed profitable to the lender. The bank makes the loan and obtains reserve balances and liabilities later to meet reserve requirements or withdrawals as needed.

That credit money is endogenous and that the central bank only targets directly an interest rate has nothing to do with a short-run vs a long-run phenomenon. A fundamental tenet of central banking is to defend the integrity of the payments system every day, every hour, every minute. With reserve requirements, the central bank is always operating within a maintenance period and accommodating the demand for reserve balances at the target rate. Rather than long-run vs short-run, the appropriate context is the distinction between policy tactics or operations and policy strategy. The former is about how the operating target is set, which is necessarily an interest rate target; whereas the latter is about where to place the target. While the operating target is necessarily an interest rate, this is perfectly consistent with both neoclassical or post-Keynesian strategies for adjusting the interest rate target. It is even consistent with an indirect target of a monetary 
aggregate, though it is well known that the relation between a direct interest rate target and monetary aggregates has often been unreliable in practice, including the 1979-1982 period in the US. Again, contrary to the loanable funds view, an understanding of the reality of endogenous money places the day-to-day operations of banks, central banks, and money markets, all in the process of creation of credit money, at the center of analysis.

If the loanable funds approach is inapplicable, this has significant implications. Obviously, this means that the financial 'crowding out' view of fiscal policy is inapplicable as there is no limited pool of 'funds' available to lend that a government deficit can drain. Indeed, from basic accounting, and as shown above, a deficit itself creates saving for the non-government sector. If banks are not mere intermediaries, then models of the macroeconomy cannot abstract from them just on the business cycle's ascent, obviously, but also on its descent. Just as a bank loan is created from 'nowhere,' so is the repayment of a loan a destruction of both it and the deposit used for repayment. There is no transfer of funds from the payee to the payer that the payee then can spend; even if this were the case, this again confuses an increase in the income of the payee with a portfolio shift from a loan to a deposit. Since banks are not operationally constrained in their lending, macroeconomic models must focus on what does constrain them: the existence of creditworthy borrowers (as opposed to New Consensus models that abstract from the possibility of default), sufficient capital, and the estimated profitability of a loan. Of course, these and their evolution over the course of a business cycle have been central for decades in the work of Hyman Minsky and others.

Mehrling (2011) argues that the Fed became the dealer of last resort during the financial crisis and its aftermath, which was a natural intrusion into a financial system for which liquidity is normally driven by two-way dealer markets. He focuses on the distinction between market liquidity (the ability to meet payment commitments and refinancing, often via the ability to use assets as collateral in repos) and funding liquidity (the ability to finance asset expansion). This distinction is consistent with and complementary to the endogenous money view of banking and central bank operations - in the US, the Fed's indispensable defense of the payments system provides market liquidity for banks, albeit indirectly in the Treasury repo market. The private dealer system in the money markets then sets rates in other money markets via arbitrage against the Fed's target rate given the given the guarantee of support for the latter. As a result, money markets provide funding liquidity for banks in the sense that banks can reliably obtain liabilities at roughly the Fed's target rate as they grow their assets (provided that such expansion is profitable, of course, and capital is sufficient).

The dealer-markets perspective with the central bank as provider of market liquidity in interbank markets is consistent with the endogenous money view of the central bank's necessary accommodation of banks' demand for reserve balances. Dealers set prices and let quantity vary, and central banks similarly set a target rate and adjust the quantity according to bank demand at the target rate. Both approaches thus suggest that there is no role for price discovery in the interbank market as a result. The dealer-markets perspective further supports the endogenous money view of lending and credit money since funding liquidity is not constrained by reserve requirements given the necessary role of the central bank's provision of market liquidity to support the payments system. This is true whether reserve requirements are 0 percent or 100 percent. And whereas the endogenous money perspective makes clear that credit money is endogenously created even under a gold standard or currency board regime (in the accounting sense, a loan necessarily creates a deposit), the dealer-markets view 
illustrates the constraints to funding liquidity and frequent disruption of the payments system in such systems given that the central bank cannot provide market liquidity to defend the national payments system without limitation.

In the US, the breakdown of the two-way private dealer system in the money markets and capital markets, Mehrling argues, is what drove the Fed to become the dealer of last resort. Viewing in particular the Fed's credit-easing activities in this way is useful and again consistent with the endogenous money view. Rather than the rise in the monetary base driving lending and money creation as in the money multiplier model, the Fed simply took a portion of money market dealer activity onto its balance sheet. Again, complementary to the endogenous money view, there is no reason to view such dealer activity as exogenously driving inside money creation. Further, just as dealers are about setting prices rather than targeting a particular quantity, the Fed's actions as a dealer were about setting prices (that is, rates) in money markets, again just as the endogenous money view would argue. From both perspectives, the Fed's further actions in QE1, QE2, and QE3, in which it entered capital markets to purchase Treasury notes and mortgage-backed securities, were less effective than they could have been in lowering rates: since the stimulative effect of these operations is related to altering interest rates set in dealer markets rather than raising the monetary base, announcing a desired rate rather than a quantity would have been more consistent with the Fed's actual role in the financial system.

Both perspectives also call into question the Fed's pre-crisis practice of strongly encouraging overnight credit related to payment settlement to occur off its balance sheet as a result of its own strong discouragement of banks from using its own standing overnight facilities (even as it provided intraday credit rather liberally). As the provider of market liquidity to the overnight interbank market, that it does so indirectly via repos with primary dealers and is not a direct counterparty to banks results in private money market complications related to counterparty risk in times of market stress (Kregel 2008). Whereas the Fed attempts to minimize its own exposure to credit risk, managing that risk in other ways (given that the point here is systemic risk and the risks banks are taking, not the Fed's own risk of not being able to meet its payments if a bank does not repay at maturity) while engaging in more direct, dealer-like intervention as in overdraft systems (see, for instance, Lavoie 2003; 2005) or as a direct counterparty via permanent provision of excess balances with IOR set at the target rate (for example, Lacker 2006; Kregel 2009), might be more in line with its necessary role defending the integrity of the payments system under both normal and abnormal circumstances (see Fullwiler 2009 for more discussion). Indeed, Mehrling's support of a permanent dealer-of-last-resort role for the Fed is more than a bit reminiscent of Minsky's long-held view that discount-window use should be greatly expanded and should largely supplant open market operations.

\section{CONCLUSION}

If the crisis and recession that followed have taught the economics profession anything, it should have been that 'plumbing matters,' as Mehrling (2011) puts it. This means that the details of central bank operations matter; how banks make loans and create credit, how dealer markets set prices and provide funding and market liquidity, matter; and as a result, understanding how transmission mechanisms of monetary policy actually do or do not work matters. Unfortunately, the prevalence of the inapplicable money multiplier model and the ubiquitous view that exogenous 
control over a monetary aggregate drives the macroeconomy makes it difficult to understand banking and the true nature of central bank operations in both normal and abnormal times. If the desire to spend more than income is what leads to the creation of a loan and thus a deposit, then this is very different in character than suggesting that the desire to spend is generated by a portfolio shift from a savings account to a deposit account or to currency. While one desiring to spend might move balances from a savings account to a deposit account or to currency (or might not, given credit cards or the ability to do the portfolio shift after the purchase), forcing such a portfolio shift through monetary policy does not in and of itself generate a desire to spend. The same goes for a move between deposits and Treasury securities - with highly liquid dealer markets providing continuous bids and funded at the margin by banks that are necessarily unconstrained by reserve requirements (given market and funding liquidity necessarily provided by the central bank) - that one holds a Treasury security cannot constrain spending just as holding a deposit does not necessitate it.

Finally, to understand the 'plumbing,' one must understand that accounting matters. The business model of a financial institution is to generate a return on equity through leverage. Banks want deposits because they are the cheapest liability, particularly given minimum capital requirements, not to finance operations. Any monetary policy action that raises spending through a portfolio shift or reduced interest rates necessarily does so by raising the leverage of the private sector. On the other hand, fiscal policy actions - helicopter drops - raise private sector income and reduce private sector leverage, which can be achieved many ways - from traditional spending and tax cuts to massive central bank purchases that significantly alter market prices and thus create net capital gains for the private sector (though also risk creating asset price bubbles in the process) - and also have vastly different transmission mechanisms and multiplier effects on private sector spending. In the end, an economics profession that does not understand accounting has little chance of understanding the business model of financial institutions and the inherent differences in terms of the impacts on financial statements of the private sector of alternative macroeconomic policy options. It thereby has less chance of providing appropriate policy advice for dealing with the procyclical nature of the capitalist financial system, the aftermath of serious financial crises, or recessions driven by the private sector's desire to deleverage.

\section{ACKNOWLEDGMENT}

Special thanks to an anonymous referee for helpful comments that led to improvements in this paper. All remaining errors are mine.

\section{REFERENCES}

Anderson, Richard G. 2008. 'Monetary Policy's Third Interest Rate.' Federal Reserve Bank of St. Louis Monetary Trends (July), 51-72.

Anderson, Richard G. and Robert H. Rasche. 2001. 'Retail Sweep Programs and Bank Reserves, 1994-1999.' Federal Reserve Bank of St. Louis Review, 83 (1) (January/February), 1-24.

Bech, Morton L. and Tara Rice. 2009. 'Profits and Balance Sheet Developments at U.S. Commercial Banks during 2008.' Federal Reserve Bulletin (June), A57-A97. Available at: http:// www.federalreserve.gov/pubs/bulletin/2009/pdf/bankprofits09.pdf.

Ennis, Huberto M. and Todd Keister. 2008. 'Understanding Monetary Policy Implementation.' Federal Reserve Bank of Richmond Economic Quarterly, 94 (3), (Summer), 235-263. 
Federal Reserve. 2012. 'Fedwire Funds Service Annual Data.' Available at: http://www. federalreserve.gov/paymentsystems/fedfunds_ann.htm.

Friedman, Benjamin and Kenneth Kuttner. 2010. 'Implementation of Monetary Policy - How Do Central Banks Set Interest Rates?' Available at: http://web.williams.edu/Economics/ wp/FriedmanKuttnerImplementationOfMonetaryPolicy.pdf.

Fullwiler, Scott T. 2003. 'Timeliness and the Fed's Daily Tactics.' Journal of Economic Issues, 37 (4), 851-880.

Fullwiler, Scott T. 2005. 'Paying Interest on Reserve Balances - It's More Significant than You Think.' Journal of Economic Issues, 39 (2), 543-550.

Fullwiler, Scott T. 2008. 'Modern Central Bank Operations - The General Principles.' Available at: http://papers.ssrn.com/sol3/papers.cfm?abstract_id=1658232.

Fullwiler, Scott T. 2009. 'The Social Fabric Matrix Approach to Central Bank Operations: An Application to the Federal Reserve and the Recent Mortgage Meltdown.' In: Tara Natarajan, Wolfram Elsner, and Scott T. Fullwiler (eds), Institutional Analysis and Praxis: The Social Fabric Matrix Approach, New York, NY: Springer, pp. 123-170.

Gagnon, Joseph, Matthew Raskin, Julie Remache, and Brian Sack. 2010. 'Large-Scale Asset Purchases by the Fed: Did They Work?' Staff Reports No. 441 (March). New York: Federal Reserve Bank of New York.

Goodfriend, Marvin. 2002. 'Interest on Reserves and Monetary Policy.' Federal Reserve Bank of New York Economic Policy Review, 8 (May), 77-84.

Hamilton, James D. and Jing Wu. 2011. 'The Effectiveness of Alternative Monetary Policy Tools in a Zero Bound Environment.' Mimeo. Available at: http://dss.ucsd.edu/ jhamilto/zlb.pdf.

Keister, Todd, Antoine Martin, and James McAndrews. 2008. 'Divorcing Money from Monetary Policy.' Federal Reserve Bank of New York Economic Policy Review, 14 (1) (September), 41-56.

Keister, Todd and James McAndrews. 2009. 'Why Are Banks Holding so Many Excess Reserves?' Federal Reserve Bank of New York Current Issues in Economics and Finance, 15 (8) (December), 10 pp., available at: www.newyorkfed.org/research/current_issues/ci15-8.pdf.

Kregel, Jan. 2008. 'A Simple Proposal to Resolve the Disruption of Counterparty Risk in ShortTerm Credit Markets.' Jerome Levy Economics Institute Policy Note 2008/4 (October).

Krugman, Paul. 2011. 'The Problem with Quasi-Monetarism.' The New York Times (September 13).

Lacker, Jeffrey M. 2006. 'Central Bank Credit in the Theory of Money and Payments.' Speech at the Economics of Payments II Conference, Federal Reserve Bank of New York (March 29).

Lang, Richard W. 1980. 'The FOMC in 1979 - Introducing Reserve Targeting.' Federal Reserve Bank of St. Louis Review (March), 2-25.

Lavoie, Marc. 2003. 'A Primer on Endogenous Credit Money.' In: Louis-Philippe Rochon and Sergio Rossi (eds), Modern Theories of Money - The Nature and Role of Money in Capitalist Economies. Cheltenham, UK and Northampton, MA: Edward Elgar, pp. 506-543.

Lavoie, Marc. 2005. 'Monetary Base Endogeneity and the New Procedures of the Asset-Based Canadian and American Systems.' Journal of Post Keynesian Economics, 27 (4), 689-710.

Lavoie, Marc. 2010. 'Changes in Central Bank Procedures during the Subprime Crisis and Their Repercussions for Monetary Theory.' International Journal of Political Economy, 39 (3), 3-23.

Martin, Antoine and James McAndrews. 2008. 'Should There be Intraday Money Markets?' Federal Reserve Bank of New York Staff Report No. 337 (July).

Martin, Antoine, James McAndrews, and David Skeie. 2011. 'A Note on Bank Lending in Times of Large Bank Reserves.' Federal Reserve Bank of New York Staff Reports No. 497 (May).

Mehrling, Perry. 2011. The New Lombard Street - How the Federal Reserve Became the Dealer of Last Resort. Princeton, NJ: Princeton University Press.

Meulendyke, Ann-Marie. 1988. 'Can the Federal Reserve Influence Whether the Money Supply Is Endogenous? A Comment on Moore.' Journal of Post Keynesian Economics, 10 (1), 390-397.

Moore, Basil. 1988. Horizontalists and Verticalists: The Macroeconomics of Credit Money. Cambridge, UK: Cambridge University Press.

Volcker, Paul. 1980. 'The New Federal Reserve Technical Procedures for Controlling Money.' Appendix to a Statement before the Joint Economic Committee (June 1). 